American Journal of Agricultural and Biological Sciences 6 (3): 377-383, 2011

ISSN 1557-4989

(C) 2011 Science Publications

\title{
Global Warming at the East Coast Zone of Peninsular Malaysia
}

\author{
Hayrol Azril Mohamed Shaffril, Bahaman Abu Samah, \\ Jeffrey Lawrence D'Silva and Jegak Uli \\ Laboratory of Sustainable Development and Agriculture Extension, \\ Institute for Social Science Studies, University Putra Malaysia, Malaysia
}

\begin{abstract}
Problem statement: Global Warming is not a new phenomenon and it is already been felt by people all around the world. Not only the people affected by the global warming, but also our sea. There are a lot of potential threats that can be caused by global warming on the sea such as rise of sea level, changes in waves action, water current and wind velocity, but do one of the main users of the sea which are the fishermen have already felt these impacts? Approach: This is a quantitative study where a developed questionnaire was used to gain the data needed. Through a stratified random sampling a total of 300 registered fishermen from four states in the east coast zone of Peninsular Malaysia namely Kelantan, Terengganu, Pahang and East Johor have been selected. Results: This study provided a greater understanding of the fishermen views on the changes that happened to the sea due to the global warming impact. They stressed that the temperature, the rainfall season and the coastal areas have changed. Furthermore, according to them, the sea nowadays are no longer easy to predict as the water current, wind velocity and wave's actions can easily change their pattern and endanger them while they are at the sea. Conclusion/Recommendation: Effective actions can be taken to assist the fishermen to adapt to impacts of global warming. One of it is to provide them with more information on global warming. Besides, fishermen in Malaysia also can be provided with trainings in order to provide them with other skills besides fishing.
\end{abstract}

Key words: Global warming impact, social adaptation, fishermen, east coast zone

\section{INTRODUCATION}

What is Global warming?: The threats of global warming nowadays cannot be lightly taken by the community. This global phenomenon not only bring threats to the environment but also to the main users of the environment; Human. Global warming happens when the earth heats up (the temperature rises). It happens when the "greenhouse effect" (referring to certain gases in Earth's atmosphere) trap heat. These gases let in light but keep heat from escaping, like the glass walls of a greenhouse. The process will involve the sunlight shines onto the Earth's surface, there it will be absorbed and then radiates back into the atmosphere as heat. In the atmosphere, "greenhouse" gases trap some of this heat and the rest escapes into space. The more greenhouse gases are in the atmosphere, the more heat gets trapped. It is expected that the global temperatures will rise up to 1.5 and $4.5^{\circ} \mathrm{C}$ over the next century (Nelson and Serafin, 1996).

Global warming in Malaysia: Global warming has already been experienced by the community in
Malaysia. Wai et al. (2005) have detected a significant increase of the mean annual temperature, ranging from $0.99-3.44^{\circ} \mathrm{C}$ per 100 years and they also have detected that global warming trend in Malaysia has increased in the past 30 years. International Panel on Climate Change (IPCC) has supported the study done by Wai et al. (2005) when they found that the average temperature in Malaysia is predicted to increase between $0.6-4.5^{\circ} \mathrm{C}$ in 2060. Moreover, according to Deni et al. (2008), the frequency of long dry period tended to be higher with a significant increase in the mean and the variability of the length of the dry spells whereas all of the indices of wet spells in these areas show a decreasing trend. Atikah has stressed that even though Malaysia is categorized as a country with a moderate risk towards global warming impact, the flood disaster that happened at Johor, Pahang, Kedah and Kelantan has proven that the impact of global warming can endanger us. Tangang (2007) has emphasized that Malaysian must be ready to face the threats of the global warming as it will cause gradual increase in temperature, extreme events such as flood, drought and storm and shift in

Corresponding Author: Hayrol Azril Mohamed Shaffril, Laboratory of Sustainable Development and Agriculture Extension, Institute for Social Science Studies, Universiti Putra Malaysia, Malaysia 
climate patterns. Furthermore, the global warming also will exposes people to numbers of threats on their socio-economic aspects (Mia et al., 2011; Rashid et al., 2011; El-Nesr et al., 2010; Fuller and Harhay, 2010; Yan and Wu, 2009; Hamdi et al., 2009).

The global warming impact on the sea: One of the most affected elements of the global warming is our sea. In the fisheries industry, global warming has been identified to cause threats in air and inland water temperatures, changes in solar radiation, changes in sea surface temperature, changes in other oceanographic variables (current, wind velocity and wave actions, increase in frequency and intensity of extreme events and water stress. These changes will create physiological (growth, development, reproduction, disease), ecological (organic and inorganic scales, predation and ecosystem services) and operational (species selection, site selection,) changes. Besides the sea, threats that are caused by global warming especially on the coastal areas bring problems to us. World will become hotter and the sea level will rise by the expanding ocean water. Based on the research done by The International Panel on Climate Change (IPCC), the global average sea level is expected to rise between 0.6 and 2 feet (0.18-0.59 meters) in the next century McCarthy (2001) and Aung et al. (2009). Furthermore, coastal areas and coastal wetland systems are also affected by the global warming (McCarthy, 2001). Sea level rise also increases the vulnerability of coastal areas to flood during storms for several reasons. Shore erosion also increases vulnerability to storms, by removing the beaches and dunes that would otherwise protect coastal property from storm waves (FEMA 2000). Sea level rise also increases coastal flooding from rainstorms, because low areas drain more slowly as sea level rises. Other impacts of global warming may further enhance or mitigate coastal flooding. Flooding from rainstorms may become worse if higher temperatures lead to increasing rainfall intensity during severe storms. An increase in the intensity of tropical storms would increase flood and wind damages. Coastal water supply is also affected by global warming. Rising sea level increases the salinity of both surface water and ground water through salt water intrusion. If sea level rise pushes salty water upstream, then the existing water intakes might draw on salty water during dry periods. Salinity increases in estuaries also can harm aquatic plants and animals that do not tolerate high salinity. Based on the literature reviews, it is obvious that the sea has suffered from the global warming impact, the question that can be raised now is; are the fishermen in Malaysia which is among the main users of the sea has already experienced the impact of global warming? This study has the answer for this question.
Background of fisheries industries in the east coast zone of Malaysia: Fisheries is one of the main industries in Malaysia. The importance of this industry in ensuring the continuity of the food supply in Malaysia cannot be denied.

The east coast zone of Peninsular Malaysia is one of the major contributors for this supply. As been depicted in Table 1, there are 17 fisheries districts in Malaysia where 11 of the districts are located at Terengganu, 4 at Kelantan and 3 each at Pahang and East Johor Fig. 1.

Table 2 has presented the number of registered fishermen in the east coast zone of Peninsular Malaysia. As in 2009, a total of 32,565 fishermen were registered and this number represents more than a quarter of overall registered fishermen in Malaysia. Terengganu has the biggest number of registered fishermen with 10,421 followed by Kelantan with 9,624 registered fishermen, Pahang with 7,024 registered fishermen and East Johor with 5,496 registered fishermen. Bachok and Pasir Puteh (Kelantan) is the district with the highest number of registered fishermen (6430), followed by Kuantan (Pahang) with 3,720 registered fishermen and Mersing (Johor) with 3,041 registered fishermen.

Table 3 presents the number of productivity of the fishermen of the east coast zone of Peninsular Malaysia. Data presented has shown us that there was instability in terms of the productivity. There is a possibility that global warming is one of the contributors of this instability. In 2005 the number of productivity was 318,642 tonnes and increased to 386,263 tonnes in 2006, however, in 2007 a decrease in the fisheries industry productivity in the east coast zone of Peninsular Malaysia was recorded where there was only a total of 336,099 tonnes. In 2008 the productivity recorded was 361,578 tonnes; an increase of 25,479 tonnes compared to the last year productivity. However, once again the productivity recorded showed a decrease in 2009 where a total of 334,864 tonnes has been landed, a decrease of 26,714 tonnes.

Table 1: Fisheries districts on the east coast zone of Peninsular Malaysia

\begin{tabular}{ll}
\hline States & Fisheries districts \\
\hline Kelantan & Tumpat \\
& Kota BHaru \\
& Bachok \\
Terengganu & Pasir puteh \\
& Besut \\
& Setiu \\
& North kuala terengganu \\
& South kuala terengganu \\
& Marang \\
Pahang & Dungun \\
& Kemaman \\
Johor (East) & Kuantan \\
& Pekan \\
& Rompin \\
& Mersing \\
& North kota tinggi \\
& South kota tinggi \\
\hline
\end{tabular}


Am. J. Agri. \& Biol. Sci., 6 (3): 377-383, 2011

Table 2: Number of registered fishermen at east coast zone of Malaysia

\begin{tabular}{lc}
\hline States/Districts & $\begin{array}{c}\text { Number of registered } \\
\text { fishermen }(2009)\end{array}$ \\
\hline Kelantan & \\
Bachok and pasir puteh & 6430.0 \\
Tumpat & 1744.0 \\
Kota bharu & 1450.0 \\
Total & 9624.0 \\
Terengganu & 2356.0 \\
Besut & 2135.0 \\
South kuala terengganu & 1874.0 \\
Kemaman & 1224.0 \\
Marang & 1196.0 \\
Dungun & 876.0 \\
North kuala terengganu & 760.0 \\
Setiu & 10421.0 \\
Total & \\
Pahang & 3720.0 \\
Kuantan & 1987.0 \\
Rompin & 1317.0 \\
Pekan & 7024.0 \\
Total & \\
Johor (East) & 3041.0 \\
Mersing & 1321.0 \\
South kota tinggi & 1134.0 \\
North kota tinggi & 5496.0 \\
Total & 32565.0 \\
Overall total &
\end{tabular}

Table 3: Productivity of east coast fishermen in Malaysia (in tonnes)

\begin{tabular}{ll}
\hline Year & Productivity \\
\hline 2005 & 318.642 \\
2006 & 386.263 \\
2007 & 336.099 \\
2008 & 361.578 \\
2009 & 334.864 \\
\hline
\end{tabular}

\section{MATERIALS AND METHODS}

Based on the stratified random sampling employed, a total of 300 registered fishermen were selected as the respondents. The number was gained from four states located at the east coast zone of Peninsular Malaysia namely Kelantan, Terengganu, Pahang and East Johor. Each of the states was represented by 75 respondents. To gain the data needed, an instrument was developed and pre-tested earlier before the actual data collection took place. There are four elements of the environment included in the instrument and the elements were (1) temperature; (2) sea; (3) rain and (4) coastal area. The questions included on the instrument were gained from the previous studies conducted on the global warming impact on the sea. For each of the question the respondents were asked on their agreement on the global warming impact on the four elements. For each of the question the respondents were given a five likertlike scale answer ranging from 1-strongly disagree; 2 disagree; 3- moderately agree; 4-agree and 5-strongly agree. SPSS was used to run analyses such as frequency, percentage, mean and standard deviation.

\section{RESULTS}

Before we go to our main objective, it is better for us to look at the socio-demographic data of the respondents. Based on the results presented in Table 4, we can see that the respondents studied are the "senior" fishermen based on the mean score of age recorded which 42.21 years. Majority of the respondents $(26.3 \%)$ were in the group age 41-50 years, followed by those in the group age of 51-60 years $(25.0 \%)$ and those in the group age of 31-40 years (19.0\%). In term of level of education, we can see that more than half of the respondents $(51.3 \%)$ possessed a primary school level of education while $22.0 \%$ of them possessed SPM/SPMV level of education. It is a concern for us to know that the average income per month recorded for the respondents was RM669.62 which is below the poverty level set by government (>RM720). Majority of the respondents $(45.3 \%)$ were detected to gain below RM500 per month. A total of $52.0 \%$ of the respondents have less than 5 household members while the remaining $48.0 \%$ have more than 5 household members. The mean score recorded for the experience of being the fishermen was 25.10 years which indicates to us that the respondents studied are experienced fishermen. A total of $14.1 \%$ of the respondents do have more than 41 years of experience of being a fisherman. The mean score recorded for days going out to the sea for catching fish was 18.90 days and majority of them (39.3\%) went out to the sea between 16-20 days in a month. A large majority of the respondents $(71.0 \%)$ were the coastal area fishermen.

Is the world getting hotter nowadays? Table 5 has clarified to us the data regarding the perceptions of the fishermen towards the changes of the environment (temperature). A total of three statements have been asked to the respondents and the highest mean score was recorded by the statement of "temperature gets hotter in your area (land) $(\mathrm{M}=3.61)$, this is followed by the statement of temperature gets hotter in your area (sea) $(\mathrm{M}=3.57)$ and the lowest mean score was recorded by the statement of "the area here become too dry" $(M=3.34)$.

In term of the respondents' perception towards the changes of the environment (sea), a total of four questions have been asked. It is a big concern for us to discover that a large percentage of the respondents answers were concentrated on agreed and strongly agreed on each question asked. For the statement of "the weather at the sea is unpredictable nowadays" a total of $47.0 \%$ agreed on this statement while $41.7 \%$ of the respondents strongly agreed on this statement. 
Am. J. Agri. \& Biol. Sci., 6 (3): 377-383, 2011

Table 4: Socio-demographic data of the respondents

\begin{tabular}{|c|c|c|c|c|}
\hline & Frequency & Percentage & Mean & SD \\
\hline Age (years) & & & 42.21 & 12.96 \\
\hline$\leq 30$ & 42 & 14.0 & & \\
\hline$\overline{3} 1-40$ & 57 & 19.0 & & \\
\hline $41-50$ & 79 & 26.3 & & \\
\hline $51-60$ & 75 & 25.0 & & \\
\hline$\geq 61$ & 47 & 15.7 & & \\
\hline \multicolumn{5}{|l|}{$\overline{\text { Level of education }}$} \\
\hline Never been to school & 21 & 7.0 & & \\
\hline Primary school & 154 & 51.3 & & \\
\hline PMR/SRP* & 55 & 18.3 & & \\
\hline SPM/SPMV** & 66 & 22.0 & & \\
\hline Skill certificates & 3 & 1.0 & & \\
\hline Degree/Master/PhD & 1 & 0.3 & & \\
\hline \multicolumn{3}{|l|}{ Income per month (as a fisherman) (in Ringgit Malaysia) } & 669.62 & 724.71 \\
\hline$<500$ & 136 & 45.3 & & \\
\hline $501-750$ & 99 & 33.0 & & \\
\hline$>751$ & 65 & 21.7 & & \\
\hline \multicolumn{3}{|l|}{ Number of household } & 5.77 .0 & 2.53 .0 \\
\hline$<5$ members & 156 & 52.0 & & \\
\hline$>5$ members & 144 & 48.0 & & \\
\hline \multicolumn{3}{|l|}{ Experience as a fisherman (years) } & 25.10 & 14.29 \\
\hline$<10$ & 61 & 20.3 & & \\
\hline $11-20$ & 82 & 27.3 & & \\
\hline $21-30$ & 58 & 19.3 & & \\
\hline $31-40$ & 56 & 18.7 & & \\
\hline$>41$ & 43 & 14.3 & & \\
\hline \multicolumn{3}{|l|}{ Average (days) going out to the sea for catching fish } & 18.90 & 4.86 .0 \\
\hline$<15$ & 93 & 31.0 & & \\
\hline $16-20$ & 118 & 39.3 & & \\
\hline$>21$ & 89 & 29.7 & & \\
\hline \multicolumn{5}{|l|}{ Category of fishermen } \\
\hline Coastal area & 213 & 71.0 & & \\
\hline Deep sea & 87 & 29.0 & & \\
\hline
\end{tabular}

Lower Secondary School Education Certificate; Malaysia Education Certficate/Malaysia Vacational Education Certificate

Table 5: Perceptions of respondents towards the changes of the environment (temperature)

\begin{tabular}{|c|c|c|c|c|c|c|c|}
\hline Statement & $\begin{array}{l}\text { Strongly } \\
\text { disagree }\end{array}$ & Disagree & $\begin{array}{l}\text { Moderately } \\
\text { agree }\end{array}$ & Agree & Strongly & $\begin{array}{l}\text { Mean } \\
\text { agree }\end{array}$ & SD \\
\hline Temperature gets hotter in your area (land) & 2.3 & 12.7 & 24.7 & 42.0 & 18.3 & 3.61 & 1.00 \\
\hline Temperature gets hotter in your area (sea) & 1.7 & 14.0 & 30.0 & 34.3 & 20.0 & 3.57 & 1.01 \\
\hline The area here become too dry & 2.0 & 19.0 & 32.3 & 36.3 & 10.3 & 3.34 & 0.97 \\
\hline
\end{tabular}

Table 6: Perceptions of respondents towards the changes of the environment (sea)

\begin{tabular}{|c|c|c|c|c|c|c|c|}
\hline Statement & $\begin{array}{l}\text { Strongly } \\
\text { disagree }\end{array}$ & Disagree & $\begin{array}{l}\text { Moderately } \\
\text { agree }\end{array}$ & Agree & $\begin{array}{l}\text { Strongly } \\
\text { agree }\end{array}$ & Mean & $\mathrm{SD}$ \\
\hline The weather at the sea is unpredictable nowadays & 0.7 & 5.0 & 5.7 .0 & 47.0 & 41.7 & 4.24 & 0.82 \\
\hline The water current at the sea are uncertain nowadays & 0.7 & 7.0 & 9.7 .0 & 47.3 & 35.3 & 4.10 & 0.89 \\
\hline The waves actions are uncertain nowadays & 3.3 & 9.0 & 17.4 & 38.3 & 32.0 & 3.87 & 1.07 \\
\hline The wind velocity are uncertain nowadays & 1.0 & 6.3 & 7.3 .0 & 46.3 & 39.0 & 4.16 & 0.88 \\
\hline
\end{tabular}

A total of $47.3 \%$ of the respondents agree on the statement of "water current at the sea are uncertain nowadays" while $35.3 \%$ of the respondents strongly agreed on this statement. For the statement of "the wave's actions at the sea are uncertain nowadays" $38.3 \%$ of the respondents agreed on this statement while $32.0 \%$ of the respondents strongly agreed on this statement. Nearly half of the respondents $(46.3 \%)$ agreed on the statement of "the wind velocity at the sea are uncertain nowadays" while nearly two fifth of the respondents (39.0\%) strongly agreed on this statement (Table 6).
The respondents also were asked regarding their perception towards the changes of the environment (rain). A total of three questions have been asked and the highest mean score was recorded by the statement of "the rainfall season is uncertain nowadays" ( $\mathrm{M}=$ 3.99), followed by the statement of "more frequent rain in this area" $(\mathrm{M}=3.25)$ and "more frequent thunderstorm in this area" $(\mathrm{M}=2.99)$ (Table 7).

The last questions asked to the respondents were focusing on their perception towards the changes of the environment (coastal areas). Based on the results portrayed on Table 8, we can see that more than half of the respondents $(57.0 \%)$ agreed on the statement "the coastal area is eroded". 
Am. J. Agri. \& Biol. Sci., 6 (3): 377-383, 2011

Table 7: Perceptions of respondents towards the changes of the environment (rain) (in\%)

\begin{tabular}{|c|c|c|c|c|c|c|c|}
\hline Statement & $\begin{array}{l}\text { Strongly } \\
\text { disagree }\end{array}$ & Disagree & $\begin{array}{l}\text { Moderately } \\
\text { Agree }\end{array}$ & Agree & $\begin{array}{l}\text { Strongly } \\
\text { Agree }\end{array}$ & Mean & SD \\
\hline The rainfall season is uncertain in this area & 1.7 & 5.3 .0 & 9.4 .0 & 59.3 & 24.3 & 3.99 & 0.84 \\
\hline More frequent rain in this area & 1.3 & 22.0 & 35.4 & 33.3 & 8.0 & 3.25 & 0.93 \\
\hline More frequent thunderstorm in this area & 4.0 & 31.7 & 31.7 & 26.7 & 6.0 & 2.99 & 0.99 \\
\hline
\end{tabular}

Table 8: Perceptions of respondents towards the changes of the environment (coastal areas)

\begin{tabular}{|c|c|c|c|c|c|c|c|}
\hline Statement & $\begin{array}{l}\text { Strongly } \\
\text { disagree }\end{array}$ & disagree & $\begin{array}{l}\text { Moderately } \\
\text { agree }\end{array}$ & Agree & $\begin{array}{l}\text { Strongly } \\
\text { agree }\end{array}$ & Mean & SD \\
\hline The coastal area are eroded & 2.3 & 13.3 & 11.3 & 57.0 & 16.0 & 3.71 & 0.97 \\
\hline $\begin{array}{l}\text { Number of fish landed in this coastal } \\
\text { areas are reducing }\end{array}$ & 2.0 & 12.0 & 13.0 & 51.0 & 22.0 & 3.79 & 0.98 \\
\hline $\begin{array}{l}\text { The coastal area become more shallow } \\
\text { Lots of coral reef have been destroyed }\end{array}$ & 4.3 & 20.7 & 19.3 & 35.0 & 20.7 & 3.47 & 1.16 \\
\hline by the uncertain whether & 7.7 & 21.7 & 27.0 & 27.3 & 16.3 & 3.23 & 1.18 \\
\hline Mangrove areas are reducing & 14.7 & 36.3 & 15.7 & 25.7 & 7.7.0 & 2.75 & 1.21 \\
\hline
\end{tabular}

Daerah-Daerah Perikanan, Malaysia

Fisheries districts, Malaysia

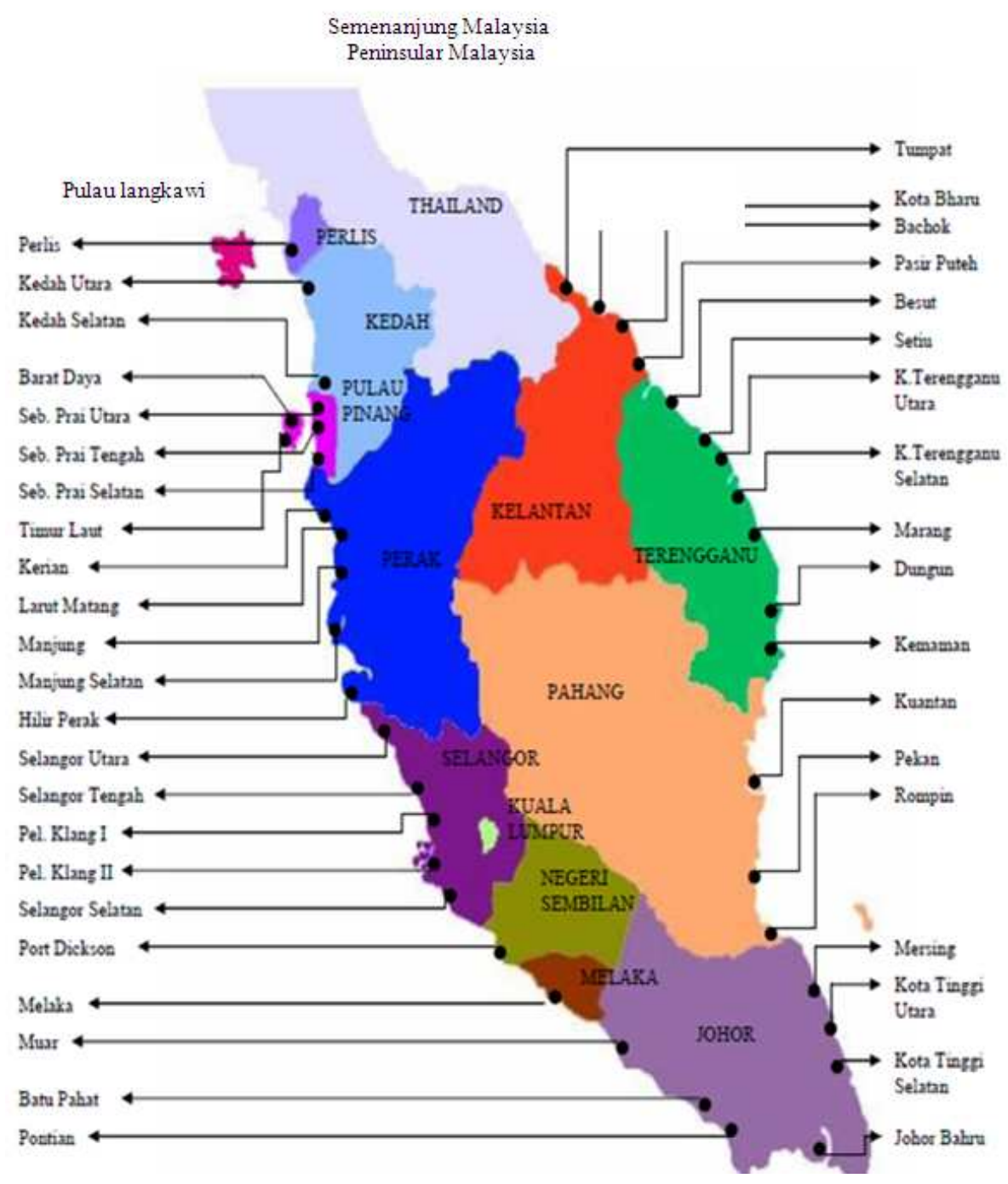

Fig. 1: Fisheries districts on the east coast zone of Malaysia 
More than one third of the respondents (36.3\%) signalled their disagreement towards the statement of "mangrove areas are reducing". Majority of the respondents $(73.0 \%)$ were agreed and strongly agreed when they were asked regarding are the number of fish landed in the coastal areas are reducing. A total of $27.3 \%$ of the respondents agreed on the statement of "lots of coral reef have been destroyed by the uncertain whether" while a total of $27.0 \%$ of the respondents moderately agreed on this statement. More than one third of the respondents $(35.0 \%)$ agreed on the statement of "the coastal area become more shallow".

\section{DISCUSSION}

Agriculture has be one of the economic drivers for Malaysia and has be the effective mechanisms in enhancing the community standard of living (D'Silva et al., 2011; Shaffril et al., 2010; Uli et al., 2010; Samah et al., 2011) and it needs to be sustained as our dependent on this industry is high. As one of the agriculture branches fiheries industry is important However, due to several causes, the sea nowadays which is one of our main sources of protein has never been the same as before. Interestingly, our findings have revealed that majority of the fishermen agreed that their area (land and sea) are getting hotter nowadays; the obvious indicator of the global warming impact. Our findings here has something to do with a study done by Tanggang et al (2006), whereby he stressed that temperature in Malaysia has increased between 0.5 Celsius to 1.5 Celsius in the last 40 years and interestingly three of the studied areas were in Kuantan, Mersing and Kota Bharu which located at the east coast zone of Peninsular Malaysia. Furthermore, Wai et al. (2005) have detected a significant increase of the mean annual temperature, ranging from 0.99 to $3.44^{\circ} \mathrm{C}$ per 100 years and they also have detected that global warming trend in Malaysia has increased in the past 30 years. Majority of the respondents agreed and strongly agreed on the statement of the "rain season is uncertain nowadays" and "more frequent rain in this area", our findings has been supported by study done by Tanggang et al. (2006) in their study have revealed that since 1980s there are increasing number of days of extreme rainfall event and thunderstorm over Peninsular Malaysia including at the east coast zone of Peninsular Malaysia. This study also has revealed that a large majority of the respondents has agreed that the wind velocity, waves actions and water current at the sea are uncertain and this is not surprising as according to McCarthy (2001), global warming will cause threats in air and inland water temperatures, changes in solar radiation, changes in sea surface temperature, changes in other oceanographic variables such as water current, wind velocity and wave actions. The coastal areas at the respondents' areas have changed negatively due to the global warming. In a study done by McCarthy (2001), have revealed that land loss is another negative impact brought by global warming. Coastal areas and coastal wetland ecosystems including salt marshes and mangroves are particularly vulnerable to rising sea level because they are generally within a few feet of sea level (McCarthy, 2001). Effective actions can be taken to assist the fishermen to adapt to the impacts of global warming. One of it is to provide them with more global warming information. Perhaps with this kind of information they will know what to expect and get ready for it. Providing fishermen with training for developing their skills other than fishing is an essential step. Fishermen can seek for another job with the new skill developed if one day they are no longer able to be fishermen due to global warming impact.

\section{CONCLUSION}

Based on the results gained, it can be seen that majority of the respondents have agreed on one thing; the global warming has changed the sea and the environment at their areas. Majority of the respondents agreed that the sea nowadays are unpredictable and there are uncertainties in the pattern of the sea elements such as water current, wind and waves. The fishermen interviewed also agreed that the rain season is uncertain nowadays. They also agreed that their area; on the land and on the sea are getting hotter while they informed that their coastal areas were eroded.

\section{REFERENCES}

Aung, T., A. Singh and U. Prasad, 2009. Sea level threat in tuvalu. Am. J. Applied Sci., 6: 1169-1174. DOI: 10.3844/ajassp.2009.1169.1174

D'Silva, J.L., N. Man, H.A.M, Shaffril and A.S. Bahaman, 2011. Acceptance of sustainable agriculture practice: The case of crop farmers. Am. J. Agric. Biol. Sci., 6: 227-230. DOI: 10.3844/ajabssp.2011.227.230

Deni, S.M., A.A. Jemain and K. Ibrahim, 2008. The spatial distribution of wet and dry spells over Peninsular Malaysia. Theoretical Applied Climatol., 94: 163-173. DOI: 10.1007/s00704-0070355-8

El-Nesr, M.N., M.M. Abu-Zreig and A.A. Alazba, 2010. Temperature trends and distribution in the arabian peninsula. Am. J. Environ. Sci., 6: 191203. DOI: 10.3844/ajessp.2010.191.203

Fuller, A.C. and M.O. Harhay, 2010. Population growth, climate change and water scarcity in the southwestern united states. Am. J. Environ. Sci., 6: 249-252. DOI: 10.3844./ajessp.2011.249.252 
Hamdi, M.R., M. Abu-allaban, A. Al-Shayeb, M. Jaber and N.M. Normani, 2009. Climate change in jordan: A comprehensive examination approach. Am. J. Environ. Sci., 5: 58-68. DOI: 10.3844./ajessp.2009.58.68

McCarthy, J.J. IPCC, 2001. Climate change 2001: impacts, adaptation and vulnerability: Contribution of Working Group II to the third assessment report of the Intergovernmental Panel on Climate Change. 1st Edn., Cambridge University Press, ISBN: 0521015006 , pp: 1032.

Mia, M.S., R.A. Begum, A.C. Er R.D.Z.R.Z. Abidin and J.J.P. Malaria et al., 2011. Climate change: Discussion on economic impact. Am. J. Environ. Sci., 7: 65-74. DOI: 10.3844./ajessp. 73.82

Nelson, J and R. Serafin, 1996. Environmental and Resources Planning and Decision Making in Canada: A Human Ecological Approach and Civics Approach. In: Canada in Transition: Results of Environmental and Human Geographical Research, Vogelsang, R. (Ed.). Brockmeyer University, pp: 191-191. ISBN: 3819604138

Rashid, M., J.J. Pereira, R.A. Begum, S. Aziz and M.B. Mokhtar, 2011. Climate change and Its Implications to national security. Am. J. Environ. Sci., $\quad 7$ : $150-160$. DOI: 10.3844/ajessp.2011.150.160
Samah, B.A., H.A.M. Shaffril, M.A. Hassan and J.L. D'Silva, 2011. Can technology acceptance model be applied on the rural setting: The case of village development and security committee in Malaysia. J. Soc. Sci., 7: 113-119. DOI: 10.3844/jssp.2011.113.119

Shaffril, H.A.M., J.L. D'Silva, J. Uli and A.S. Bahaman, 2010. Gender issues in contract farming: the case of Malaysian students. Am. J. Agric.Bio.Sci., 5: 204-209. DOI: 10.3844/ajabssp.2010.204.209

Tangang, F., 2007. Climate Change and Global Warming: Malaysia Perspective: Malaysia Perspective and Challenges. Paper presented at UKM Public Speech, Anuar Mahmud Hall, University Kebangsaan Malaysia.

Uli, J., J.L. D'Silva, Shaffril, H.A.M. and A.S. Bahaman, 2010. the attitude, belief, support and knowledge level of the youth and their acceptance towards agriculture contract farming. J. Soc. Sci., 6: 350-355. DOI: 10.3844/jssp.2010.350-355

Wai, N.M., A. Carmelengo and A.A.W. Khairi, 2005. A study of global warming in Malaysia. J. Technol., 42: $1-10$.

Yan, S. and G. Wu, 2009. What these trends suggest?. Am. J. Applied Sci., 6: 1116-1121. DOI: 10.3844/ajassp.2009.1116.1121 